Article

\title{
Sporting Space, Sacred Space: A Theology of Sporting Place
}

\section{Robert Ellis}

Regent's Park College and the Faculty of Theology and Religion, University of Oxford, Regent's Park College, Pusey Street, Oxford OX1 2LB, UK; robert.ellis@regents.ox.ac.uk

Received: 27 June 2019; Accepted: 7 August 2019; Published: 10 August 2019

Abstract: Religion often designates locations that are considered sacred, marked off from ordinary space. Sporting venues also take on a significance for players and supporters that is seldom adequately explained in solely sporting terms. Can theological understandings of place illuminate the way in which players and spectators relate to the 'sacred space' of their sporting endeavors? In this paper, I explore and assess the theological and religious significance of sporting space by reflecting upon descriptions of both religious and sporting special places. I use a range of types of descriptions of experiences of such spaces together with theological ideas and concepts, including Christian notions of incarnation, sacrament, and Trinity, which are found to be useful resources, undermining a strict binary of 'sacred' and 'profane' space. I then build upon previous theological and empirical work with sports participants to explore a theological understanding of special sporting places and the experiences of those who play and support sporting endeavors in them.

Keywords: place; sacred space; religion and sport; theology and sport; sacrament

\section{Introduction}

Religion often designates 'special' places-locations that are considered sacred and are marked off from ordinary space. Ninian Smart's seminal work includes such places among the 'material' dimension of religion (Smart 1998, pp. 22-24). For Smart, the material dimension of religion encompasses triptychs, crucifixes, and fonts, as well as the elements of oil, bread, wine, and water deployed in sacramental observance. It also includes complex sites, such as the Ganges or Jerusalem, as well as locations such as white-washed dissenting chapels and baroque Cathedrals. What each of these material artifacts has in common is not mere religious utility but a capacity to carry and convey meaning and to mediate the experiences to which they witness. Furthermore, whether formally or informally, these artifacts have been made, or are regarded as, 'special' — separated or set apart, 'holy', or 'sacred'.

Sporting venues also take on a complex significance for groups of players and supporters that is seldom adequately explained in solely sporting terms and that-prima facie-seems similar in certain respects to that of special religious places. Some sporting locations are invested with iconic significance and have national and international resonance: one thinks, for instance, of Augusta's golf course or Lord's cricket ground. However, even local venues may take on the nature of 'hallowed turf'. Some sports clubs present their venues as sites for quasi-religious practices, with ashes of former players or spectators scattered or memorial events being staged there. Others offer less formal but rhetorically developed understandings (see Liverpool FC 2018).

Can the notion of 'sacred space' help us understand special sporting places and can it further help to explain the apparently (quasi-)religious experiences that sports participants often have in these locations? In this paper, I explore and assess the theological and religious significance of sporting space and raise the question for future work of whether such an understanding of sporting places sheds light back upon religious locations. 
I begin by offering descriptions of experiences of two Christian and two sporting special places-a process that will allow some initial similarities to become obvious before I critically consider theological notions of 'place'. The Christian doctrines of incarnation, sacrament, and Trinity are deployed to this end. In this paper, a particular focus will be placed upon the notion of sacrament, but this, in turn, draws upon Christian ideas of incarnation. Additionally, the doctrine of the Trinity is useful, in particular, because it underlines the way in which God may be affirmed as present and active in the world while still allowing for clear differentiation between God and the world. These three doctrines undermine a strict binary between the 'sacred' and the 'profane', but the designation of especially holy places ('sacred space') is still useful. I then build upon previous work with players and supporters to explore the way in which sporting places may be experienced by analogy with religious 'places' and how both serve to mediate the experiences of the communities that gather within them. Particularly important for the theological concepts discussed here is the idea of self-transcendence and its grounding in the human person, who is understood to be made in the image of God. Insofar as sporting places may be described as sacred and sporting experiences may be described as religious experiences, I suggest that human self-transcendence is close to the heart of the matter. However, given the scope of this essay, it will not be possible to explore these aspects in detail (though I have addressed them elsewhere): the focus here is on 'place'.

A word must be said about the vocabulary of 'space' and 'place'. In popular conversation, the expression 'sacred space' is used frequently. However, academic discourse increasingly draws a distinction between 'space' and 'place'. The difference is nicely expressed by theologian Oliver O'Donovan:

"Place" differs from "space," in that space is prior to culture and inhabitation, whereas place is the way we come to experience space when we have made our home in it. A "place," therefore, is the fruit of civilization, an area of space that has been distinguished from other areas by the inhabitation of a community. (O'Donovan 1989, p. 46)

Some writers see notions of 'space' as ideologically fraught, attempting to suggest a neutrality-a void in which things may or may not happen; and thus, the physicality of our actual space is diminished (e.g., Bartholomew 2011; Inge 2003). By contrast, 'place' is storied and the locus of embodied existence. As O'Donovan goes on to stress, a 'place' need not have a current population but is nevertheless construed by the human relationship to it. We understand our natural world, including those parts of it where the human imprint is faintest, according to a complex set of cultural factors (Sheldrake 2001, p. 16). Nevertheless, in general:

[T]o think of a place is at once to think of a natural space on the one hand and of the community that is defined in relation to it on the other. It is to grasp the reciprocal relationship between nature and culture; geographical space mediating a possibility for human life in community; human inhabitation elevating dead space into the character and distinctness of place. (O'Donovan 1989, p. 47)

In this essay, I tend to speak about 'place' rather than 'space' but also use the term 'sacred space', recognizing that this expression is part of our vernacular.

\section{Special Places}

What can the notion of 'sacred space' mean to us today? It will perhaps direct us to religious buildings and sites where nature and religion seem symbiotically connected or to some other location where the descriptor 'sacred' might jar or surprise. My first two examples of special Christian sites are not comprehensive, but they are representative and suggestive. They show the interplay of environment and history with experience as well as the ambiguities of such places. From them, we will turn to two examples of special places in sport. 


\subsection{Sites of Celtic Pilgrimage}

Twenty years ago I took a Celtic tour, visiting the Holy Island of Lindisfarne off the northeast coast of England and Iona off the west coast of Scotland. I went curious but skeptical. Brought up in the radical Protestant Baptist tradition, I was not naturally inclined toward the belief that places in and of themselves hold some kind of special aura.

Both destinations were bleakly beautiful islands with an untamed liminal feel, and the geography of both helps to create their sense of apartness. To both, a committed and careful journey is necessary. Perhaps it was the lingering morning mist; the solitariness of the location; the oddness of the tidal island's geography; the connection with the Celtic spirituality resources originating there (e.g., Adam 2010); or the long history of devotion, mission, and prayer; however, in ways I could not quite articulate, the Holy Island felt different. Somehow, 'spiritual experience' felt more possible.

On Iona, I stayed with a group of strangers in a community house. George McLeod, the Iona community's founder, was reported to have said that Iona is a 'thin place, where the veil between things spiritual and things material is as thin as gossamer' (Sheldrake 1995, p. 7; Power 2006, p. 45). McLeod was creative in his development of what one might call 'Iona mythology' (Power 2006, pp. 41-45), but his language of the 'thin place' has proved resonant and durable. While Iona bustled with visitors, it was still possible to feel something of what McLeod may have meant. The strong sense of community that built through the week was nourished by the rhythm of worship and a sense of common values and purpose. The narrative stretches back to Columba in $563 \mathrm{CE}$ and was appropriated by the Iona community, the iconic abbey with visitors washing in and out like the tide, the island's remarkable light and ever-changing weather, and its physical isolation and beauty, all gave, similar to Holy Island, a strange sense of nature and history interweaving. One morning, we sang 'Morning has broken' in the abbey while birds sang in the building's rafters, which seemed to aptly sum up the experience.

Laura Béres' accounts of three visits to Iona are found in two overlapping articles (Béres 2012a, 2012b). She reflects upon her own experience and conversations with fellow pilgrims and residents, as well as upon the island's history and geomorphology. Béres explores some of this complexity with the help of postmodern geographers, social work theorists, and writers on spirituality. Her definition of spirituality is 'the human quest for personal meaning and mutually fulfilling relationships among people, the non-human environment, and, for some, God' (Béres 2012b, p. 183. The definition is Canda's; Béres cites Zapf 2009). A key element in this definition is the inclusion of both relational and environmental aspects, and Béres draws a contrast between the very different approaches to land or place in, for example, autochthonous traditions and Eurocentric ones. The process in the West of what Weber called the 'disenchantment of the world' (Weber 1964) may be thought to be challenged by what is regarded as an ancient Celtic interest in the significance of places-an interest that appears to survive even a skeptical reading of the recent Celtic 'revival'. Béres finds that geography and spirituality are bound together in Iona, reporting that one visitor claims that 'Celtic spirituality also is in tune with the elements and the patterns and rhythm of nature and that Iona is a place in which you can be more aware of these rhythms' (Béres 2012a, p. 400).

Each of her visits produces more complex and richer reflection. Initially, it is mostly the pilgrims in view. She reports that their experience is quickened by the journey to Iona and that a sense of community nurtures spiritual awareness. One of her interviewees reported that 'each time she came to Iona she was able to listen to God better and learn through the constantly changing physical scene around her' (Béres 2012a, p. 399). The importance of both physical surroundings and community is significant in this person's sense of the specialness of place. In her diary, Béres herself describes a contrast between this 'thin place' and the 'thicker' place from which she had come:

Iona felt like home. It felt as though the saints and angels were walking with me ... I felt completely safe. And here, back in Glasgow with the Orange parade going on, it feels as though there is a thickness ... a buffer of distraction and human failing, with layers and layers of stuff and junk; a feeling of thickness rather than thinness. (Béres 2012a, p. 400) 
On subsequent visits, Béres notices other things-particularly Iona's permanent residents, of whom there are just over a hundred. She muses on the socio-political relationships and competing Christian traditions and begins to ask whether the island 'seen' by tourists and pilgrims might be an idealized version of reality: might the residents feel colonized, marginalized, and exploited by the island's religious economy? Geographers and anthropologists describe places as sites of power struggle, resistance, annexation, and absorption (Inge 2003, p. 27). What Béres finds among the residents is not only pragmatism and some bemusement about a 'sentimental' attachment to Celtic ways but also some appreciation of the benefits of visitors and the Community (Béres 2012a, p. 402). Alongside a view of Iona as a special place, a much more complex picture of the island emerges: layers of experience and perspective, as well as history, nature, economics, and social relationships. The island does not 'mean' the same thing for everyone.

\subsection{Cathedrals}

Durham Cathedral is built on a site chosen by monks from Lindisfarne in the late tenth century. The current building is an impressive Norman edifice begun around a hundred years later. It has a fine collection of stained glass, and the remarkable rose window dapples the stone floor with color, while the vaulted ceiling strains toward the heavens. When I visited, I paused at the chapel dedicated to a local infantry regiment, musing on its appropriateness, and then at the shrine to Cuthbert of Lindisfarne and the tomb of the chronicler Bede. As I sat quietly in the nave, the silver cross on the altar caught the light. Amid the gentle echoes, there was a sense of peace and wonder.

Many readers will have had similar experiences in such buildings, with their blend of the universal and local. Perhaps we recall the remarkable light flooding through the lantern above the central crossing at Ely, the stunning modern stained glass and Sutherland's Christ in Majesty in Coventry, the numinous intimacy of St. David's, the contemporary space window and Darth Vader gargoyle in Washington, D.C., or the awesome, organic wonder of the still-growing La Sagrada Familia in Barcelona. Such places commonly evoke silence, reverence, and awe, connecting, in a mysterious way, those present with something other worldly.

Systematic theologians begin their magna opera in various ways. Graham Ward begins his by describing his entry into Christ Church Cathedral in Oxford. 'The air is cool, the shadows deep and in the silence distant sounds reverberate' (Ward 2016, p. 3). By referencing 'deep shadows' and 'unheard sounds', Ward guides his readers to this sense of awe and mystery commonly reported in such magnificent buildings and prepares his readers for an apophatic strain in what will follow. Ward's cathedral is a different sort of space from the city's ordinary streets or its distinctive covered market:

I tread more softly; my pace is slower; and my posture bends or cranes according to what I am seeing and trying to understand. Although I have been here a thousand times I can't domesticate the place ... it is a holy space; a space within which I am taught that name, that God, that who or what or operation circulating among so many of my other more mundane beliefs. (Ward 2016, p. 3)

He goes on as follows:

It's not just the religious symbolism—crosses, an octagonal font, and the vast eagle across whose back is stretched a heavy Bible. It's not just that prayer has been said here for over a millennium. There is some inherent quality to this place, difficult to define, that makes it holy, that generates and requires holy practices that make us holy ... This is a place invested with care and value and attentiveness where people have wept and petitioned and fumbled for words and delighted. (Ward 2016, pp. 3-4)

In contrast to Iona and Lindisfarne, the physical environment that interacts with history here is primarily a human construction, and Ward observes that the holy practices of the cathedral connect worshippers with their Anglo-Saxon, medieval, and reformation forbearers, as each generation has 
shaped the space. It is a reminder that, as some of Béres' geographers put it, places always have a temporal as well as a spatial dimension (Béres 2012b, p. 178; referring to Massey 2009, p. 59); indeed, places without a temporal narrative are often characterized as 'wilderness' (Inge 2003, p. 38; Brueggemann 1978, p. 40). Ward notes some details of this space: the vaulted ceiling; the quality of the light falling on the sandstone pillars; the rich coloration of stained glass and clergy vestment; the aroma of incense and candle; the surfaces of brass, silver, and wood; the textures of the fabric; the impressive surge of the organ and the delicacy of choir song; the cruciform shape of the whole; and the altar and its cross. The cathedral has its own pedagogy, he observes: architecture and practices alike teach us what it is to believe in the Father, Son, and Holy Spirit.

However, the 'seams' of temporality in the space are not its only complexities. Ward draws our attention to dissonance as well as harmony and to the multiple and multifarious motivations that have produced the artifact in which Christians now worship (in this regard, see Brown 2004, p. 23). The temptation is to treat it as one morally unambiguous and coherent space-timeless and without history; however, it is a much more layered and complex reality. In this, the cathedral not only serves to open up the ground of a lived theology but also resembles that theology, which he says is always earthed, embodied, allusive, and oriented to worship but also flawed, self-interested, and ideological (Ward 2016, pp. 34, 144).

Space, even here, in the most obviously 'holy' of places, is neither devoid of human input nor lacking in ambiguity. It may be God's space, but it is also human space. Despite its ambiguities, the place evokes and nourishes an experience of the reality to which it testifies.

\subsection{The Millennium Stadium}

I meandered through the streets in the heart of the city with one of my sons and an old friend with whom I shared this walk decades ago as schoolboys. This time my son was sharing the 'pilgrimage' with us. We were walking into a shared past, and we recalled episodes from it as we headed toward the Millennium Stadium. This 'cathedral' is built on the site of Cardiff Arms Park, where Wales has played international rugby games for generations. Bleddyn, Barry, JPR, and Gareth-the names of the 'saints' resonate in Wales and in rugby, though they may be meaningless elsewhere. The stadium itself is similar to many other modern sports arenas. The turf is carefully laid and manicured, its emerald surface adds a touch of 'nature' to the concrete stands, and the grass alone sometimes produces gasps of wonder as fans emerge from the tunneled staircases. Nearby runs the River Taff, adding elements to the distinctive location of the stadium and its mythology. The sense of continuity with the past is strong.

This stadium was barely twenty years old, but in it, we were connected to past wonders ('on the site of $f^{\prime}$ ). It felt special. Inside, the crowd sang fragments of hymns and poured out devotions to their team; to today's chosen ones (chosen similar to priests representing communicants); to some idea of Wales—of 'us'; and to some connection with and valorization of a certain past—fact and fiction. That day, Wales beat Italy handsomely, and the singing continued. 'Bread of heaven, bread of heaven, feed me 'til I want no more ... ' The experience in this place creates an identity that lives outside it, but what happens here nourishes and maintains it.

Yet, not everyone in Cardiff that day tingled with the occasion. For some, this was an opportunity to make some money as seventy-five thousand people flooded into the city; for others, the crowds were a nuisance and the game an irrelevance. Even the faithful were divided about who should be playing and especially about how their game-the nation's game-was organized away from this match: the 'cathedral' flourished, but the 'parishes' were in a mess.

Poet and novelist Owen Sheers became the first 'writer in residence' of any national rugby team when he took up that position with Wales in January 2012. His poem Now and Then (Sheers 2012) was published in the matchday program for Wales' game against France- - the game Wales had to win in order to secure a rare grand slam by beating all the other teams in the tournament. 
Sheers captures something of the 'meaning' of the Millennium Stadium for Welsh rugby when he speaks of the way in which 'a nation becomes a stadium ... moments when the many, through the few, become one'. The experience of 'Welshness' and its connection to rugby and to this place goes some way toward explaining why the stadium is experienced as special, separated. Space and time flow together, community is invoked and imagined, heroic acts and selfless sacrifices are recalled, something similar to worship and awe is felt, and the whole seems apart from ordinary reality. There is delight in beauty and grace as well as in power and determination. There are moments of surprise and suspense and of quiet and expectancy. Symbols of Wales are scattered everywhere. Sheers suggests that the whole 'land' is made somehow sacred by its association with this playing field in the center of Cardiff, deploying a cross-linguistic pun—pridd is Welsh for 'soil' and just a letter away from 'pride'. Those who watch are constituted by their shared action: 'A nation watching, sharing a pulse/as the clock counts up to the final whistle'. Wales' relationship to this place may be distinctive, but to fans of other sports, much will sound familiar.

\subsection{West Ham United: Upton Park and the London Stadium}

A further sporting example makes the point through negative contrast-the case of West Ham United FC and its stadium move in 2016. Once again, issues of history and physical space are interwoven.

West Ham had played at Upton Park since 1904, but the stadium had become increasingly unsuitable. After a controversial process, the team won the right to become tenants at the London Stadium, which is a few miles from Upton Park and was built for track and field events for the 2012 Olympics. However, being tenants with various restrictions has limited the ways in which they can make it 'feel like home'. An arena built for track and field is very different from Upton Park, where stands closed intimately and intimidatingly around the pitch. At the London Stadium, supporters behind the goals (where many diehard fans prefer to be) feel detached from the action, and sideline distances are still big. The stadium was 'converted' for football use through a system whereby the front tier seats were moved forward over the running track, creating a gap between the front and rear seats, increasing spectators' sense of isolation from the action and one another. Instead of feeling like a familiar (if slightly dilapidated) family home, the London Stadium is said to be a soulless corporate venue.

I interviewed lifelong West Ham fan ('Hammer') about the move. Hammer's parents had grown up in the West Ham area, and Hammer had attended games regularly since the age of 8 . The Upton Park he remembered changed a lot over the years. Views were obscured by pillars, but crowd acoustics were good. He recalled the stadium as 'a bit shabby', even tacky at times. Notwithstanding, he said, 'it was home', and, significantly, 'they are mystical places, right?'

He recalled great wins, dismal failures, and shared match days with school friends, college friends, work colleagues, and family. He built new friendships with those who sat around him regularly. Hammer cherished what he called the 'match day ritual': parking in a similar place, going to the same café, and seeing other regulars do the same. This sense of the occasion 'beyond the stadium' is noted by others: 'I used to go to Upton Park, grab a program, nip in the pie and mash, have a bet, into the boozer, meet my pals, all good, have a laugh, then out afterwards [to the match]' (Anthony 2018). This sense of the significance of the journey to the stadium echoes dimly the pilgrims' experience and is in marked contrast with the experience of fans at the London Stadium. According to Hammer, the journey to London Stadium is neither as easy, as was promised, nor as convivial. He complains of feeling 'managed' through traffic systems in a characterless location. Moreover, there are problems with seating and remoteness, poor crowd acoustics, and the very visible presence of tourists in other clubs' shirts, which all add to problems of poor team performance, making the match day experience border on toxic-setting fans not only against the club's board but also sometimes against one another. The lack of any visual continuity with Upton Park serves to underline further the break: neither the statues of famous players nor the quiet grove in which fans' ashes were scattered-nor anything else, for that matter-was brought to, or replicated in, this new place. 
Ward spoke of the pedagogy of the cathedral, and stadia too have their own pedagogies through which fans are educated in the tradition of the community associated with that special place. A fan arriving at Manchester United's Old Trafford is taught about the greatness of their club in various ways. A Spurs fan at their newly rebuilt stadium has visual cues as well. At the London Stadium, there is no pedagogy.

Hammer believes that a poor start in results has delayed the opportunity to build up new memories of memorable performances or to develop the balanced way in which fans mull over defeat and disappointment. Over time, these things will come, he thinks, though it is difficult to ignore an undercurrent of regret in his words, suggesting that things will never be the same as they were.

Anthony's article tells a similar story (see also Russell 2018; Stone 2017), reporting that the new stadium is 'soulless', and referring to Upton Park as the club's 'spiritual home'. Anthony observes that 'what has upset the fans this season is not the loss of a football match so much as the loss of an identity' (Anthony 2018). Another fan complains, 'we have given up our history, our heritage, our legacy, all of which was focused on Upton Park'. Such claims may seem overblown to those who are not invested in sports; however, places that bear a history create a people. In the interweaving of physicality and narrative and symbols and memories, places become special, 'sacred'. They evoke and nourish certain kinds of experience. This is not to deny an element of nostalgia. Upton Park moments are recalled with some rose-tinting. As it was becoming unsuitable for modern football, the area around it was changing rapidly as well, such that ' ... Upton Park represented a link to a disappeared past ... ' (Anthony 2018).

Anthony demonstrates, similar to Béres and Ward in different ways, the layered nature of special places, both sporting and ecclesial, and the ambiguities that are connected with such places when we tease away at the layers. What we find, again, is that 'real' places present many facets for examination. Christian places of worship and theologies are earthed, embodied, allusive, and oriented to worship, as well as flawed, self-interested, and ideological. They are sometimes constructions of our imaginations, which 'edit out' aspects of their reality. In similar ways, our other special places also present their ambiguities, if we choose to look and see; yet, these ambiguities do not rob them of their 'specialness'.

\section{Theological Resources for Place and 'Sacred Space'}

\subsection{Initial Considerations}

Protestant theologians have tended to be wary of ascribing any particular significance to special places, and if they do, they tend to insist that such specialness is simply a function of the people who have become associated with these places (see White 1995; Walker 1990,1992). It was often argued that the New Testament (NT) spiritualizes the Old Testament (OT) approach to the land, and thereby to place generally, and that Christianity replaces the OT concern with place with a universally available risen Jesus (Davies 1974). Nowhere is special anymore.

The work of Walter Brueggemann has prompted a re-evaluation of this thesis. Brueggemann argues that a special place, specifically the land, is the Bible's central theme. He speaks of 'place' as a location

[W] hich has historical meanings, where some things have happened which are now remembered and which provide continuity and identity across generations [where] important words have been spoken which have established identity, defined vocation and envisioned destiny [and] in which vows have been exchanged, promises have been made, and demands have been issued ... (Brueggemann 1978, p. 5)

In recent years, some Protestant traditions have begun to take the concept of special places more seriously (the Iona and Northumbrian communities are examples), and some Evangelical writers have similarly shown themselves to be more open to the subject. Tom Wright, for instance, speaks of his 'slow turning away from various forms of dualism, to which Evangelicalism is particularly prone, and towards the recognition of the sacramental quality of God's whole created world' (Wright 
1999, p. 4). He recalls attending a concert in a school building that had previously been a church, in which he had a strong sense of 'the presence of God, gentle but very strong', noting that he 'had no theology by which to explain why a redundant United church should feel that way' (Wright 1999, p. 4). Sociologist E.V. Walker's remark that 'human experience makes a place, but a place lives in its own way' (Walker 1988, p. 2) perhaps hints at something similar. But how can we account for this theologically? As Wright acknowledges, until recently, it was usually Catholic writers who offered the theology he lacked to account for the specialness of places, which was usually based on the doctrines of incarnation or sacrament; however, this has begun to change.

\subsection{Incarnation}

The incarnation, it is typically argued, suggests that God's concern with reaching out to humankind is not merely universal, for every time and place, but engages particularity. The incarnate Word lives a human, emplaced life-in a particular culture and period and in a sequence of particular places. Sheehy insists that 'this appears to be a principle of God's working with us' (Sheehy 2007, p. 16). He quotes Thomas Torrance: 'While the incarnation does not mean that God is limited by space and time, it asserts the reality of space and time for God in the actuality of His relations with us, and at the same time binds us to space and time in all our relations with Him' (Torrance 1969, p. 67, cited Sheehy 2007, p. 19). William Temple's claim that Christianity may be said to be the most materialistic of the major world faiths (Temple 1934) is often cited. Matter exists in space, and if God expresses Godself through material, then God may also express Godself in place.

Human emplacedness is key here:

To be human is to be placed: to be born in this house, hospital, stable (according to Luke), or even, as in the floods in Mozambique in 2000, in a tree. It is to live in this council house, semi-detached, tower block, farmhouse, mansion. It is to go to school through these streets or lanes, to play in this alley, park, garden; to shop in this market, that mall; to work in this factory, mine, office, farm. These facts are banal, but they form the fabric of our everyday lives, structuring our memories, determining our attitudes. (Gorringe 2002, p. 1)

\subsection{Sacrament}

The materiality of a sacrament is clearly an associated notion. As with incarnation, it suggests a divine choice and promise to communicate and mediate grace through material means. The historical development of ideas of sacrament has been controversial, but in the twentieth century, a creative renewal of theological thinking has led to the notion of Christ as the sacrament of God (Schillebeeckx 1963) and, following Vatican II, the idea of the Church as sacrament and even 'the brother as sacrament' (Balthasar 1958, pp. 142-55). A number of thinkers now speak of a 'sacramental universe' (Temple 1934; Macquarrie 1997; Sheldrake 2001; Bartholomew 2011). This may sound similar to the Quaker view that all of life is sacramental, but we should add an important qualification. To affirm the possibility that God may mediate his gracious love through a material thing is not to suggest that there is anything automatic about this-a view that might be thought to lead towards pantheism (Inge 2003, pp. 66-68). Rather, to speak of the sacramental is to speak of an event and, in particular, of a divine action. These are 'the rents in the opacity of history where God's concrete engagement to change the world becomes visible' (Gorringe 2002, p. 165)-language that recalls McLeod's talk of 'thin places'. A place, viewed sacramentally, is a material location through which God mediates saving presence and grace. To claim this in a meaningful way is to claim that the place is experienced in this way repeatedly—or 'reliably', as one might say—while recognizing the divine initiative and eschewing any suggestion of something quasi-magical.

As Brown suggests, Christianity's wariness about giving spiritual worth to 'ordinary places' stems from a tendency to downplay the value of the world and a concern that 'human beings might themselves set the conditions under which God could be experienced' (Brown 2004, p. 21). He observes that this objection might be made about the Church's sacraments as well, and this, in turn, leads us to 
suggest that the hesitation about 'ordinary places' might be occasioned less by the possibility that we could control the conditions under which we experience God than a concern that we cannot control them-or, more to the point, that the Church cannot control them. A sacramental understanding of place comes up against our ideologies and self-interest.

\subsection{Trinity}

More recently, Gorringe and Bartholomew have been among those suggesting that a Trinitarian approach can yield a positive theology of place. Gorringe, proposing a theology of the built environment, argues that all space, and thus every place, is 'potentially sacred, waiting for the moment of encounter in which it mediates God' (Gorringe 2002, p. 40). In every place, as at Bethesda, an angel can stir the waters (John 5:4). A theological justification for this can be found in Barth's emphasis on the freedom of God: while God is present in every place, this is 'not uniform but distinct and differentiated', such that God is 'free to be present in some places in a way which God is not in others' (Barth 1957, pp. 473-74, cited by Gorringe 2002, pp. 42-43).

While a fallen creation means that God's gifts are distorted and his presence is never known without ambiguity, fallenness does not mean that there is no goodness in the world or that God is not active in it or cannot be mediated through it (Gorringe 2002, p. 15). The doctrine of the Trinity is considered key to navigating the ambiguity of our experience of the world and our hope to discern God's presence within it, offering, as current theological language puts it, the grammar for speaking about God in relationship with the world and suggesting that God is both present to and different from the world. The doctrine of the Holy Spirit helps believers to find God in life, freedom, creativity, and vitality and in the forging of relationships and community. The incarnation provides a hermeneutical key with which to approach scripture and our present experience. However, the doctrine of creation ex nihilo insists on God's absolute difference from the world.

Thus, the doctrine of the Trinity works dialectically, in Lash's words, 'to indicate where God is to be found - and by denying, at each point, that what we find there is to be simply identified with God-to prevent us from getting stuck in one sidedness ... The doctrine thus leads at every turn, to both affirmation and denial' (Lash 1988, p. 267).

\subsection{Place as Sacrament}

Bringing these ideas together, we can frame a theological question regarding place. Given that God chooses particularity in the incarnation, promises to give Godself sacramentally through material, and is free to choose this place rather than that place, could it be possible that God would choose some particular places, such that they appear to evoke a sense of God's presence in and of themselves? A positive answer may appear to marginalize or discount any human element and underestimate the importance of what happens in a given place as opposed to the 'place itself'. However, the 'place itself' is an unhelpfully abstract idea. We have already noted that any place is understood through the lenses of human culture and experience and the history of human interaction (or the lack thereof) with it. One cannot understand a place without also considering its historied aspects. As indicated, definitions of 'place' combine nature and culture. Even when place is not cultivated, the way we experience 'wild' places will be shaped by cultural factors. Theological understandings of place recognize this, with evangelicals insisting on the specialness of a place residing in the people who have been associated with it and sacramentalists arguing that the specialness of place lies in the history of divine disclosure there (Inge 2003, p. 79)—complementary positions. Thus, Inge argues for a relational view of sacred places that triangulates God, people, and locations (Inge 2003, pp. 46-47, 78-89), giving greater prominence to the material location but linking it indissolubly with its community as well as divine action. Such a view needs refining and qualifying to explain both the 'new place' (such as a new church building - a place with no history of divine encounter) and the 'old place' (such as the former church building, where the people who had shared the history of divine encounter are no 
longer present to keep the memory alive; it is as if the very stones somehow held the memories), but it represents a strong building block in the argument for special places.

\subsection{Sacred and Profane?}

Vernacular talk of a 'sacred space' appears to imply a binary between that which is and is not sacred. There is a widely accepted distinction between the shrine and the shop or changing room, which is often underscored by Durkheim's seminal treatment of the sacred (Durkheim 1915, pp. 38-39) and reinforced by Eliade's insistence on the 'non-homogeneity of space' (Eliade 1959). While this prima facie appears compelling, the universalizing tendency that W.D. Davies (Davies 1974) and others propose that Christianity introduces may not so much do away with all separated or sacred space as relativize the distinction between it and other places. Nevertheless, every religious tradition maintains some form of special place-some form of the sacred; and unless certain locations are designated 'holy' in some distinct way, we may not know how 'holiness' appears in other locations (see Hegdes 2018, pp. 12-18). 'God is omnipresent but that does not mean that his presence can therefore be felt everywhere equally ... [and] foci help ...' (Brown 2004, p. 386).

The hard distinction maintained by both religious and sociological/anthropological discourse is not one that can be accepted straightforwardly by Christian theologians, as our consideration of the above doctrines makes clear. We must insist that while some places are separated off in their special sacredness, we should not miss the potential of every place to be holy ground-as Moses found in the desert, confronted by the burning bush (Exodus 3). We should resist any tendency to separate 'sacred space' too rigorously and find a balance between the rejection of the notion of sacred space and the banal affirmation that every space is always sacred. There are special places, but every place has the potential to become the vehicle of divine encounter. Thus, it may be possible to affirm the following:

Earth's crammed with heaven,

And every common bush afire with God ... (Browning 1857)

Every place is God's place (Psalm 24:1) —every bush can flame with God's presence. What the above-considered doctrines suggest is that this is neither automatic nor controllable by human agency. God determines, in divine freedom and grace, where and when God acts and is known. Nevertheless, the divine promise, also given in freedom and grace, appears to commit to (we might say 'covenant' with) humankind to encounter us at particular locations and in particular ways. These 'places', we have seen, are complex, ambiguous, and historied sites, always defined in some respect by human interaction with them. Some are 'obviously' special, established for the purpose of communing with God, whereas others appear more accidentally so. While we may feel close to God in a cathedral, we might have similar experiences in other locations as well (Gorringe 2002, p. 37). Sporting locations might be counted among the other places that might be or become special.

Tillich's theology of culture is useful in conceptualizing this relativization. For Tillich, religion and culture are not different spheres occupying, as it were, separate spaces within the cultural landscape-sacred and profane. Rather, the religious is present, potentially, in every aspect of life as the 'dimension of depth', which directs our attention to 'that which is ultimate, infinite, unconditional in man's [sic] spiritual life' (Tillich 1975, p. 7). In every 'preliminary concern, ultimate concern is present, consecrating them' (Tillich 1975, p. 41). Thus, every place, even those not designed or designated as 'sacred', can open up to us this dimension of depth. Sport is a cultural activity in which the dimension of depth may open up, and sporting locations may mediate this limpidity.

\section{Sporting Places as Sacramental Locations}

Bain-Selbo asserts 'that human beings act religiously in ways other than those restricted to institutionalized religion, ... that the sacred is not restricted to one's church, and that spiritual communities can be formed outside of stereotypically religious congregations' (Bain-Selbo 2009, p. 232). 
We now consider sporting spaces as material locations in which people 'act religiously' and form some kind of 'spiritual community' by reflecting upon their sacramental character.

The sacramental character of special places should not be restricted to 'natural' places, nor specifically to 'religious buildings' (in affirming this, Brown also considers homes, gardens, and whole cities: Brown 2004, p. 245). A brief consideration of the ways in which Brown argues that church architecture conveys and elicits meaning (their 'pedagogy') will be helpful. His study concentrates on the ways in which buildings focus a sense of transcendence or immanence or both. Key to the former is often the way in which light is used by architects to suggest an 'other worldly' light and also to draw congregants towards it worshipfully. Similarly, and most obvious in Gothic styles, the use of vertical lines in columns, towers, and spires draws the eye upwards and 'Godwards'. Both techniques rely on deeply primitive symbols for transcendence-height and light. Immanence may seem less apparent, but Brown believes that the tendency in modern church design to gather the community around the altar (or the music group, perhaps) in ways that emphasize community is one way of doing this. This over-simplified sketch offers just enough to continue our analysis. In what follows, I will be thinking mainly, though not exclusively, of major venues and stadia as shared 'special' places of sport.

Approaching a modern stadium, one cannot but be struck by its considerable bulk. Concrete and sometimes glass rise from the ground impressively. We are used to large buildings, and from the outside, modern stadia are often not conventionally beautiful—though seeing the whole, or more of the whole, can add to the aesthetic pleasure (as in the aerial views so popular now on television, showing stadia in their aesthetically satisfying circular shapes). However, even by the standards of large buildings, the Millennium Stadium is big. Its massive bulk stretches up before us. Whether it is appropriate to speak of awe in such an approach remains to be seen, but some of the raw materials are there, including some of those verticals-though the more rounded, Colosseum-like shape of these structures softens them. The architects of the new Wembley Stadium incorporated allusions to the old Wembley through the new arch, expressing continuity with the past through an immediately recognizable motif. Reaching out beyond and above, straining at or toward something, the arch has practical as well as symbolic use (Wembley Stadium 2019; Tekla 2019), and similar to many a flying buttress, it looks very impressive. The pilgrims travelling up Wembley Way take all this in-the primitive symbols impacting them unconsciously-and some kind of impression is made, stirring a response.

There comes a point in the approach to a modern stadium when suddenly a view opens up of the field. Through the concrete, the light suddenly changes, and we glimpse the rich emerald of the playing surface. Many fans will feel a frisson of excitement at this view-a combination of the change in light (accentuated if there are floodlights) and the sudden burst of color amid the drab greys and beiges. This 'wow' moment can be followed by others when emerging into the stands or terrace, including the play of light on sporting uniforms. There is continuity between Brown's account of transcendence-evoking architecture in churches and the design and experience of sport's special places (if we were to consider, in contrast, golf's special places, we might need to consider Brown's analysis of cultivated gardens or depictions of nature in art to seek other clues to transcendence and immanence). Players and supporters alike report aesthetic satisfaction and enjoyment in sport. Often, these reports relate to the play rather than the arena, but not always. With the color, the light, and the sights and smells, all the fans' senses are engaged and stimulated in the stadium. This involved and involving experience demands and gives energy.

There is also immanence. Old stadia were often constructed and developed piecemeal: a terrace here; a stand there. Aligned around each side separately, they were often an exercise in getting as many people into small spaces as easily (though not as safely) as possible. Some supporters mourn the loss of the old standing terraces. The physicality of supporting a team often feels cramped by a requirement to stay seated: it is easier, perhaps, to kick and tackle with one's team's players when standing, as well as to gesticulate, sway, and generally engage in 'bodily worship'. Standing in older 
stadia, we literally 'felt' part of a community. The atmosphere in such spaces was a key part of their popularity, and this atmospheric aspect of the stadium has not disappeared in modern grounds but has, rather, been transmuted (though we recall the problematic London Stadium above). Typically, in modern stadia, the seating wraps around the pitch in a bowl-like shape, giving a feeling not unlike the congregation gathered around the altar. In Britain, a roof may keep the sound in and amplify the noise, enhancing the aural dimensions of the immersive experience. The uniformity of the seating, the noise of support, the orchestration of crowd response, and often the proximity to the playing surface all reinforce the community feel of the experience. There is a dimension of religious experience that may be categorized as 'communal' (Ellis 2014, pp. 179, 185-86), and it is close to aspects of what Brown describes in speaking of an experience of the immanence of God.

In the special sporting place marked by history, memory, words and deeds, and promises and demands, a 'nation' —or a town, community, or group of disparate individuals_-becomes a stadium', and a common sense of identity is created. Players and spectators speak of the important social bonds of special sporting places. Often these are trans-generational, connecting the living to the dead: the frequent requests for the scattering of ashes in stadia or memorial gardens adjacent to them testify to this. However, in addition to this temporal dimension that draws upon and adds to the storied layers of the experience, there is the spatial dimension that connects individuals together in the present: supporters report that a 'feeling of belonging' is generated and speak of the 'supportive family' of their clubs (Ellis 2014, p. 170). For supporters, presence at the game, at a place, is about identity and belonging (see Gorringe 2002, pp. 73-76) but also about seeking certain kinds of experience in the reciprocal relationship between players, supporters, and location. The 'sung liturgies' of sport relate to identity and identification: they used to be affirmed with team scarves and rattles but are now done so with 'replica shirts'. The impact of consumerism on these phenomena does not eclipse the reality that they project. We recall that a Trinitarian approach anticipates the ambiguities of the world. God may be mediated through such experiences without being fully identified within them. In a similar way, while the purity of the sporting experience may be debased by various factors, the reality of the experience itself remains.

The immersiveness of the experience propels some supporters and players towards those experiences of 'flow' that have so often been compared to mystical experiences (Ellis 2014, pp. 155-456, 179-80), and it appears that the material location of the stadium plays a part in this as in the generally 'religious' character of the in-stadium experience.

Modern stadia have a tendency to resemble one another in ways not always true of the oddities of old, and it may be thought that they lack charm or individuality. Some supporters think of them as 'soulless', and this sense of alienation from place is most pronounced when combined with an unwanted move away from a more familiar 'home'. The experience of Cardiff Blues' rugby supporters after the team's short-lived move to Cardiff City's soccer stadium adds testimony to our London Stadium stories. A more extreme example of exile is that of the move and renaming of Wimbledon FC to Milton Keynes in 2003. There is no sense of continuity with the old, only a feeling of betrayal and loss, deeply felt, similar to something from the Psalms.

The special places of sport are not only its great 'cathedrals' or pilgrimage destinations but may also be particular and local places associated with remembered events and relationships, longing and promise, and community and identity: large stadia and local playing fields. These places may be understood to function sacramentally in the ways in which they mediate the experience of sporting participants.

\section{Assessing the Experience of Special Sporting Places}

We now approach, at first obliquely, a question posed at the outset. Can the notion of 'sacred space' not only help us understand special sporting places but also further help to explain the apparently (quasi-)religious experiences that sports participants often report in these locations? 
I first came across Dorothy Gurney's poem 'God's Garden' when I read its closing couplet inscribed around the edge of a garden pond in the home of a devout Christian.

One is nearer God's heart in the garden

Than anywhere else on earth. (Gurney 1934, p. 9)

The gardener was a woman with a sense of place. She had an attachment to her own local church's building that was more than mere sentiment, and she took enormous pleasure and real spiritual nourishment from the natural world. She did not feel that the 'religious experience' that she had in her garden was one that belonged to a parallel realm to the experience that she had in church; it was not, as it were, a similar affective response to different 'things'. She affirmed that it was the God and Father of her Lord Jesus Christ in both cases (or perhaps the Risen Christ who met Mary in the guise of a gardener). In this, she echoed the experience of those who have often been called 'nature mystics'. Rather than worshipping divine nature, as is sometimes alleged, these nature mystics claim to have an experience of God through the materiality of nature.

We considered earlier Brueggemann's account of what 'makes' place: it is marked by historic meanings or memories of the past that provide continuity and identity through generations, and it is a location where important words and deeds have been spoken and done and where vows are made, promises given, and demands issued - all of which establishes identity, vocation, and a sense of destiny. Does this sound like a way of describing sporting sacred places? I suggest that it does rather a good job of doing so for the Millennium Stadium, for Lord's cricket ground, and for many others, including local venues. The complex interplay of factors proposed by Brueggemann illuminates some of the multifaceted sinews that bind supporters to players and clubs or teams. Here, we see how 'when the many, through the few, become one', a sense of identity is created and reinforced. Pilgrimage, itself having many layers, is driven, among other factors, by the creation and nurturing of identity, and the concept of pilgrimage proves useful for explicating significant sporting journeys. A lifelong cricket fan, when I attended my first Lord's test match a few years ago, the experience had much in common, albeit in a modest way, with a pilgrimage. Brown is correct to resist restricting 'pilgrimage' to 'religious' destinations (Brown 2004, pp. 153-54).

In our special places, that which is 'bigger' than the individual-identity, community, memory, and meaning-coalesces, construed as expressed in and carried by a location and its various elements. This is as true in a cathedral as in a sporting venue. There it is God, who Christians believe is known and experienced. What of the stadium? At the very least, it seems that the special places of sport function in a way that is analogous to the ways in which special places in religion function. A similar dynamic of community, memory, and location is at work, and the places generate their own ways of mediating and nurturing the experience. But what is this experience? Is what players and supporters sometimes report in the special places of sport an experience of some parallel but phony realm, or is it an experience of the same God known by Christians in Jesus and (sometimes) experienced in worship, prayer, and discipleship; in the sacramental materiality of bread and wine; or in the sacramental love of Christian fellowship? Is the experience known in playing or supporting a genuine experience of the transcendent, however diffracted or distorted? For while it may be appreciated that God may be experienced through the world (indeed, how else could God be experienced?), Christian theologians have also regarded it as a fallen world, a place of ambiguity, and have considered that God, who is experienced through the material is not identified wholly with it.

The experience of sports, both as a spectator (vicarious sport) and player, is an experience that is congruent with the richness of those experiences that we label 'religious'. In particular, sport offers its participants experiences that might be described as mystical, charismatic, regenerative, communal, and nurturing (Ellis 2014, pp. 179-89). The special places in which sport is played and celebrated contribute in various ways to these experiences, evoking and mediating them in a sacramental way. The desire to win, to improve one's performance, and to transcend the present self is at the heart of sport for all its participants (Ellis 2014, pp. 128, 233-48). This, too, is mediated sacramentally by place, 
which teaches, shapes, and draws out this desire, and it is the centrality of this self-transcendence that suggests that sporting experience may not be merely a substitute for religious experience but, rather, the thing itself. The restless desire at the heart of sport may be understood by reference to Rahner's description of human openness toward God and marked by a similar sense of restless desire. Rooted in human consciousness, human persons are always questioning and probing at their limits, always reaching beyond themselves, an indication that we are 'always still on the way. Every goal that [we] can point to in knowledge and in action is always relativized, is always a provisional step. Every answer is always just the beginning of a new question' (Rahner 2010, p. 34). For Rahner, every restless reaching out is ultimately a quest for God, the ground of all our probing. Seen in this light, sporting experience may have more in common with religious experience than being a mere simulacrum.

It would seem reasonable to suggest that a 'religious experience' that is self-conscious is thus in some way fuller or more complete; however, in reflecting upon the similarities and/or differences between experiences in the stadium and (for instance) those in church, it may be helpful to consider the way in which C.S. Lewis compares the values encountered in great literature with the values of the Christian faith. He regards these values as 'sub-Christian', though this expression should not be understood in the derogatory way in which one might use the term now. Instead, he suggests that, while they are something less than what Lewis regards as fully Christian values, they represent the highest level that can be attained without attaining the values of the Christian faith. He speaks of them as an anticipation (a kind of starter or hors d'oeuvre) or reflection (as the moon to the sun) of Christianity. He says, "though "like is not the same," it is better than unlike. Imitation may pass into initiation. For some it is a good beginning. For others it is not; culture is not everyone's road into Jerusalem, and for some it is a road out' (Lewis 1981, p. 40).

Seeing a stadium experience as an anticipation of a fuller and more fully aware kind of religious experience may be regarded as a useful way of comparing the two phenomena. However, Lewis' observation that not everyone will 'travel to Jerusalem' through an experience of culture-or of sport-is also helpful. As Lewis suggests, it may lead in another direction altogether, because the striving for self-transcendence that lies at the heart of sport may also become disordered (Ellis 2014, pp. 262-74). Some of the more problematic aspects of sport may form its participants in undesirable ways, and a distorted competitiveness is as likely to lead away from as toward God. However, the difficulties of sport do not eclipse its positive possibility. As Lewis also says, 'imitation may pass into initiation'.

When Brown finally comes to consider sport, it is disappointing that he only does so as a metaphor for religious experience in modern cinema. However, he indicates elsewhere that we might properly encompass sport and sporting places in a view of a world that is alive with the potential presence and action of God:

The natural world, the layout of a town or garden, the structure of a specific building, a basketball shot can all induce religious feelings that ought not to be summarily dismissed as though necessarily inferior to a Christian's experience of response to prayer or of worship in a church. God can be encountered in both types of experience alike as a given, the former exhibiting the same non-instrumental character that worship ought rightfully to have. (Brown 2004, pp. 407-8)

I submit that the foregoing suggests that, insofar as sport can be a vehicle for an encounter with the divine, it is in no small part because of the role played by its special places in mediating such experiences.

Funding: This research received no external funding.

Conflicts of Interest: The author declares no conflict of interest.

\section{References}

Adam, David. 2010. Tides and Seasons: Modern Prayers in the Celtic Tradition. London: SPCK. 
Anthony, Andrew. 2018. 'It's Soulless Here.' Why West Ham Fans are in Revolt. The Guardian. April 29. Available online: https://www.theguardian.com/football/2018/apr/29/why-west-ham-fans-are-in-revolt (accessed on 7 August 2019).

Bain-Selbo, Eric. 2009. Game Day and God: Football, Faith, and Politics in the American South. Macon: Mercer University Press.

Balthasar, Hans Urs Von. 1958. Science, Religion, and Christianity. Translated by Hilda Graef. London: Burns and Oates.

Barth, Karl. 1957. Church Dogmatics. Volume II, Part 1. Translated by Geoffrey Bromiley. Edinbugh: T \& T Clark.

Bartholomew, Craig. 2011. Where Mortals Dwell: A Christian View of Place Today. Grand Rapids: Baker.

Béres, Laura. 2012a. A Thin Place: Narratives of Space and Place, Celtic Spirituality and Meaning. Journal of Religion E Spirituality in Social Work: Social Thought 31: 394-413. [CrossRef]

Béres, Laura. 2012b. Celtic Spirituality and Postmodern Geography. Journal for the Study of Spirituality 2: 170-85. [CrossRef]

Brown, David. 2004. God and the Enchantment of Place. Oxford: OUP.

Browning, Elizabeth Barrett. 1857. Aurora Leigh. London: Chapman \& Hall.

Brueggemann, Walter. 1978. The Land: Place as Gift, Promise and Challenge in Biblical Faith. London: SPCK.

Davies, William David. 1974. The Gospel and the Land: Early Christianity and Jewish Territorial Doctrine. Berkeley: University of California Press.

Durkheim, Emil. 1915. The Elementary Forms of the Religious Life. Translated by Joseph Ward Swain. London: Allen \& Unwin.

Eliade, Mircea. 1959. The Sacred and the Profane. New York: Harcourt \& Brace.

Ellis, Robert. 2014. The Games People Play: Theology, Religion, and Sport. Eugene: Wipf \& Stock.

Gorringe, Timothy. 2002. A Theology of the Built Environment: Justice, Empowerment, Redemption. Cambridge: CUP.

Gurney, Dorothy Frances. 1934. God's Garden. In God's Garden and Other Verses. London: Burns, Oates \& Washbourne.

Hegdes, Paul. 2018. Deconstructing Religion: Some Thoughts on Where We Go from Here-A Hermeneutical Proposal. Exchange 47: 5-24.

Inge, John. 2003. A Christian Theology of Place. Farnham: Ashgate.

Lash, Nicholas. 1988. Easter in Ordinary: Reflections on Human Experience and the Knowledge of God. London: SCM.

Lewis, C. S. 1981. Christianity and Culture. In C. S. Lewis: Christian Reflections. Edited by Walter Hooper. Glasgow: Fount.

Liverpool FC. 2018. We are Liverpool: This Means More. Available online: https:/www.youtube.com/watch?v= YhqiSO_UFxg (accessed on 7 August 2019).

Macquarrie, John. 1997. A Guide to the Sacraments. London: SCM.

Massey, Doreen. 2009. For Space. London: Sage Publications.

O'Donovan, Oliver. 1989. The loss of a sense of place. Irish Theological Quarterly 55: 39-58. [CrossRef]

Power, Rosemary. 2006. A Place of Community: "Celtic" Iona and Institutional Religion. Folklore 117: $33-53$. [CrossRef]

Rahner, Karl. 2010. Foundations of Christian Faith. New York: Crossroads.

Russell, Michael. 2018. What's wrong with West Ham? A lifelong fan explains ... . GQ. March 12. Available online: https://www.gq-magazine.co.uk/article/whats-wrong-with-west-ham-a-lifelong-fan-explains (accessed on 7 August 2019).

Schillebeeckx, Edward. 1963. Christ, the Sacrament of. Translated by Paul Barrett. London: Sheed and Ward.

Sheehy, Jeremy. 2007. Sacred Space and the Incarnation. In Sacred Space: House of God, Gate of Heaven. Edited by Philip North and John North. London: Continuum.

Sheers, Owen. 2012. Now and Then. Available online: https://www.facebook.com/owensheersauthor/posts/owenspoem-for-the-france-programmenow-and-thenwhat-might-have-been-and-what-has/10150595249280614/ (accessed on 7 August 2019).

Sheldrake, Philip. 1995. Living between Worlds: Place and Journey in Celtic Spirituality. London: Darton, Longman and Todd.

Sheldrake, Philip. 2001. Spaces for the Sacred: Place, Memory, and Identity. Baltimore: John Hopkins.

Smart, Ninian. 1998. The World's Religions, 2nd ed. Cambridge: CUP. 
Stone, Simon. 2017. West Ham: Why has London Stadium move been so problematic. BBC Sport. September 12. Available online: https://www.bbc.co.uk/sport/football/42329101 (accessed on 7 August 2019).

Tekla, Trimble. 2019. Available online: https://www.tekla.com/uk/references/wembley-stadium-arching-ambition (accessed on 7 August 2019).

Temple, William. 1934. Nature, Man and God. London: MacMillan.

Tillich, Paul. 1975. Theology of Culture. London: OUP.

Torrance, Thomas. 1969. Space, Time and Incarnation. New York: OUP.

Walker, Eugene Victor. 1988. Placeways: A Theory of the Human Environment. Chapel Hill: University of North Carolina Press.

Walker, Peter W. L. 1990. Holy City, Holy Places? Attitudes to Jerusalem and the Holy Land in the Fourth Century. Oxford: Clarendon.

Walker, Peter W. L., ed. 1992. Jerusalem Past and Present in the Purposes of God. Carlisle: Paternoster.

Ward, Graham. 2016. How the Light Gets In: Ethical Life I. Oxford: OUP.

Weber, Max. 1964. The Sociology of Religion. Boston: Beacon Press.

Wembley Stadium. 2019. Available online: http://www.wembleystadium.com/about/press/stadium-facts-andfeatures (accessed on 7 August 2019).

White, Susan. 1995. The Theology of Sacred Space. In The Sense of the Sacramental. Edited by Ann Loades and David Brown. London: SPCK.

Wright, Tom. 1999. The Way of the Lord. London: SPCK Triangle.

Zapf, Michael Kim. 2009. Social Work and the Environment: Understanding People and Place. Toronto: Canadian Scholars' Press.

(C) 2019 by the author. Licensee MDPI, Basel, Switzerland. This article is an open access article distributed under the terms and conditions of the Creative Commons Attribution (CC BY) license (http://creativecommons.org/licenses/by/4.0/). 